\title{
Effectiveness of Lanterns Application on Making Lanterns Skills Improvement From Sewing Yarn for Deaf Children
}

\author{
Yolla Denara \\ Universitas Negeri Padang, Indonesia \\ denarayolla@gmail.com \\ Mega Iswari \\ Universitas Negeri Padang, Indonesia \\ mega biran@fip.unp.ac.id
}

Article History:

Received: November 08 $8^{\text {th, }} 2019$

Revised: Feb $13^{\text {th }} 2020$

Accepted: March 30th, 2020

\begin{abstract}
This study discusses the skills to make lanterns from sewing yarn for deaf children. This research is experimental research. The purpose of this study is to prove the effective lanterns application used making lanterns skills improvement from sewing yarn for deaf children. This type of research is an experimental method in the form of pre-experimental with the type of one group pretestposttest design. The subjects of this study were 5 deaf children in SLB Negeri (deaf children state) 2 Padang. This study consists of several stages, namely the first stage (pretest) to determine the initial conditions of the ability to make lanterns from sewing yarn, the second stage is given (treatment) using the lantern application, then the third stage is the last test to find out how far the results of the treatment that have been given (post-test) are processed and compared using the Wilcoxon Rank Task test. The results of research data obtained an average of pretest are 31.80 while for post-test there is an increase that is to 85.80 . Data were processed using a Wilcoxon test, obtained the value of task rank between pretest and posttest 2,032 with Asymp. Sig (2-tailed) 0.042. The probability value obtained from the analysis test is compared with the predetermined probability that is $\alpha=0.05$. The alternative hypothesis is accepted because the probability <of the established probability is $0.042<0.05$. So it is proven that the use of the lantern application is effective in improving the skills of making lanterns from sewing yarn for deaf children
\end{abstract}

Keyword: : lanterns application, Benang sewing, Deaf 


\section{INTRODUCTION}

Basically, skills will be better if they continue to be trained and honed to improve their abilities so that they can master one of the available skill areas. Skills are also often referred to as life skills (life skills), where students must have the ability to use their minds and creativity to deal with and solve problems in daily life, as well as in learning the skills of students must have life skills to work on something valuable and useful (Putri \& Iswari, 2018) .

Learning skills given by teachers to students by providing guidance and providing various opportunities that can help students to learn so that they are capable, skilled and able to create useful work. Through learning the skills taught at school it is hoped that students can develop their abilities. Students are not only equipped with the knowledge or in the academic field but as teachers must be more active and creative, they are required to equip their students by providing them with learning skills, without exception children with special needs.

Children with special needs are children who have different characteristics or characteristics of children in general and need special services. One child with special needs is Deaf (Sumekar, 2009).

Deaf is a child who has a hearing impediment, either losing the ability to hear in whole or in part or not functioning of the sense of hearing so that speech is also hampered (Sumekar, 2009). Therefore deaf children use sign language, body language, and oral language to communicate. But they are still able to carry out activities that are concrete and physically do not have obstacles.

The limitations that children with hearing impairment do not make them far from the world of education. As teachers, we must provide the education needed for the lives of students such as learning skills, given the learning of learners' skills is expected to create a productive skill.

Productive skills are things that have a sale value or can be marketed and bring huge or large profits (Putri \& Iswari, 2018). There are many productive skills such as crafts, catering, fashion, and cosmetology. The handicraft itself is in the form of handicrafts or craftsmanship that are made by themselves.

Skills learning in schools for deaf children is usually included in the learning craft (SBDP). The process of learning skills usually requires students to be creative in processing an object into a product, which is made by themselves so as to produce an item that has a useful function value and high selling value. For this reason, it is clear that deaf children can be taught skills, one of which is handicraft skills. Learning these skills emphasizes the efforts of students to produce valuable work. Based on preliminary studies conducted by researchers at SLB Negeri 2 Padang in class VIII, five children with hearing impairment were found consisting of two boys and three girls. The researcher observes the process of learning craft skills during self-development, and the researcher also asks the teacher what skills have been taught to children. So that it was found that deaf children have been taught several 
skills such as making bags and purses from yarn, arranging plastic flowers, sewing clothes and window curtains, making gadang houses from straw paper and making sandals from leather which from all of the handicrafts can be sold even the school also provides a store called PK-Style Galerryto sell the results of skills that have been made by children, but here the skill to make lanterns from sewing yarn has never been taught.

Referring to the problems found, researchers are interested in teaching a new skill, namely lanterns from sewing yarn, in the opinion of the class teacher making lanterns from sewing yarn has never been taught. Since the lanterns of sewing yarns are increasingly popular in Pakistan at various big events such as valentines, birthdays, Christmas, Chinese New Year and graduations that have a unique nuance and look colorful, many models of making lanterns from sewing yarn include sticky lanterns and carved lanterns. This creation is very interesting and unique because it can make lanterns from sewing yarn into various models.

Making lanterns from sewing yarn can be applied by combining a variety of yarn colors consisting of one or two colors at a time. In addition, the material in making lanterns from sewing yarn is very easy to get and does not spend a lot of capital. The easy way of making is also simple to produce lanterns from sewing yarn which has aesthetic value, artistic value, and high selling value.

Researchers are interested in providing learning skills for deaf children using special learning media in the form of lantern applications. Lantern application created using Android Studio. Android studio becomes the ideal IDE (Integrated Development Environment) to start developing or designing lantern applications. Lantern application is a learning media that is used to support student learning by using an Android-based advanced technology. Lantern applications can be developed and accessed by students through an android phone. Students can use this application to learn to make lanterns from sewing yarn. This lantern application is very interesting to be equipped with some icon buttons include text, images, home, KD, indicators, material and video tutorials so learning becomes more enjoyable.

Researchers choose the lantern application because when compared with other methods, the lantern application is felt to provide an opportunity for students to be able to repeat learning so that learning received by students can be understood and understood, hopefully using the lantern application can provide opportunities for deaf students to reduce understanding in words or sentences.

Based on the above problems, it can be formulated problems in conducting research as follows: "Is the application of lanterns effective in improving the skills to make lanterns from sewing yarn for deaf children of class VIII in SLB Negeri 2 Padang?". 
The purpose of this research is to prove that the application of lanterns is effective in improving the skills to make lanterns from sewing yarn for deaf children of class VIII in SLB Negeri 2 Padang.

\section{METHOD}

The research method contains the type of research used is an experiment, this method is used to determine whether the application of lanterns is effectively used in improving the skills to make lanterns from sewing yarn for deaf children of class VIII in SLB Negeri 2 Padang.

The experimental design group that can be used in this study is the Pre experimental design. Pre experimental design is often referred to as an experiment that is not actually, sometimes referred to as quasi-experiment design or pseudoexperimental experiments (Putri \& Iswari, 2018). Researchers use the form of preexperiment design because the child's behavior cannot be monitored thoroughly in the form of experiments. Researchers used one group pre-test and post-test design types (Putri \& Iswari, 2018). Then the results of the treatment can be known more clearly because it will look comparison of the results of the situation before being given treatment (treatment) after being given treatment (treatment).

The sample in this study were all deaf children of class VIII SLB Negeri 2 Padang. The population in this study was deaf children of class VIII. The research site was conducted in SLB Negeri 2 Padang, West Sumatra Province. This school is located on the street Padang Sarai, Koto Tangah, Padang, West Sumatra Province.

This study was conducted as many as 7 meetings consisting of several stages, namely the first stage in the form of an initial ability test ( pretest) to determine the total score obtained by students before being given treatment. The second step was to conduct an intervention in learning using the lantern application. The third stage is a final ability test (post-test) to see how far the results of the treatment or action that has been given.

The technique used in collecting data in this study is a test. The test is a sequence of questions, and other tools used to measure abilities or talents, knowledge and skills possessed by individuals or groups (Arikunto, 2014). The test conducted in this study took the form of an active test, in which the researcher observed, recorded and saw the results of the students' ability to make lanterns from sewing yarn with predetermined criteria. Researchers use data collection tools, namely research instruments. The instrument used by researchers in research is the act test. Act tests can be used to measure the results of the skills that students do with the form of assessment.

Forms of assessment in this skill researchers use a scale of grades 0 - 2 with its division, namely: value 0 if students cannot do it at all, value 1 if students can do it with the guidance or assistance of teachers, value 2 if students can do it themselves. 


\section{RESULTS AND DISCUSSION}

The study was conducted at SLB N 2 Pa dang with five deaf children. The collection of evidence in this experiment uses a research instrument and a way to collect evidence by an action test. The data have been obtained in the skills of making lanterns of sewing yarn processed by the techniques of data analysis suite that uses the formula test Wilcoxon Sign Rank Test.

The results of data collection in the skills to make lanterns from sewing yarn can be seen from the table below :

Table 1. Pretest and Posttest Results

\begin{tabular}{llll}
\hline No & Subject & Pretest Value(X1) & Posttest Value(X2) \\
1 & AM & 38 & 88 \\
2 & EG & 25 & 87 \\
3 & ME & 40 & 90 \\
4 & AN & 33 & 85 \\
5 & TN & 23 & 79 \\
Amount & 159 & 429 \\
\hline
\end{tabular}

From Table 1 it can be defined as a percentage of the initial ability (pretest) and ability after being given treatment or (posttest) of students.

1 Data values Pretest

The following is a statistical description of the pretest scores :

Table 2. Pretest result

\begin{tabular}{|c|c|c|c|c|c|}
\hline & $\mathrm{N}$ & Minimum & Maximum & Mean & $\begin{array}{c}\text { Std. } \\
\text { Deviation }\end{array}$ \\
\hline For Test & 5 & 23 & 40 & 31.80 & 7,596 \\
\hline $\begin{array}{l}\text { Valid N } \\
\text { (listwise) }\end{array}$ & 5 & & & & \\
\hline
\end{tabular}

From table 2, it is known that the highest value obtained by students from the pretest highest value is 40 and the lowest value is 23 . While the average value of the results of the pretest is 31.80 .

Table 3. Posttest results

$\begin{array}{cccccc} & \text { N } & \text { Minimum } & \text { Maximum } & \text { Mean } & \text { Std. Deviation } \\ \text { Post Test } & 5 & 79 & 90 & 85.80 & 4,207 \\ \begin{array}{c}\text { Valid N } \\ \text { (listwise) }\end{array} & 5 & & & & \\ \end{array}$


From table 3, it can be seen that the highest value obtained by pretest students the highest value is 90 and the lowest value is 79 . While the posttest average value is 85.80 .

After the pretest and posttest scores further, define the rank or rank of the research subjects before given her treatment (X1) and after being given treatment (X2) for tests analyzed using the Wilcoxon Sign Rank Test. In testing hypotheses, it takes conditions in the analysis of data generated by comparing Asym p Sig. (2 tailed) with a significant level $(\alpha)$. The significance level used in the analysis is 0.05 or $5 \%$ following the terms of hypothesis testing.

Table 4. Hypothesis Testing Requirements

\begin{tabular}{|c|c|c|c|}
\hline Hypothesis & $\begin{array}{l}\text { Asymp. } \\
\text { tailed })\end{array}$ & $\begin{array}{l}\text { Sig.Larafsignifikansi } \\
\text { (a) }\end{array}$ & Conclusion \\
\hline $\begin{array}{l}\text { Ho: } \\
\text { Application of lanterns } \\
\text { is not effectively used for } \\
\text { the skill of making lanterns } \\
\text { from sewing yarn }\end{array}$ & $>0.05$ & 0.05 & Ho refused \\
\hline $\begin{array}{l}\text { He has : } \\
\text { Effective lantern } \\
\text { application is used for skills } \\
\text { to make lanterns from } \\
\text { sewing yarn }\end{array}$ & $<0.05$ & 0.05 & Ha accepted \\
\hline
\end{tabular}

To prove the hypothesis that the application of lanterns can improve the skills to make lanterns from sewing yarn, the Wilcoxon sign rank test is used. The results of the analytical calculation are as follows:

Table 5. Rank between pretest-posttest

\begin{tabular}{ccccc}
\hline & & Mean & Sum of \\
Rosttest - & Negative & Rank & Ranks \\
Pretest & Ranks & $0^{\mathrm{a}}$ & .00 & .00 \\
& $\begin{array}{c}\text { Positive Ranks } \\
\text { Ties }\end{array}$ & $5^{\mathrm{b}}$ & 3.00 & 15.00 \\
& $0^{\mathrm{c}}$ & & \\
\hline
\end{tabular}

Table 6. Analysis test results

Posttest-Pretest

WITH

$-2,032^{b}$

Asymp. Sig. (2-

tailed)

, 042 
a. Wilcoxon Signed Ranks Test

b. Based on Negative Ranks

The results of the Wilcoxon task test between pretest and posttest show that the resulting value or $\mathrm{Z}_{\text {count }}=-2,032$ with probability or Asymp Sig (2-tailed) = 0.042 . The probability value obtained from the analysis test can then be compared with a predetermined probability that is $\alpha=0.05$ so that the probability is less than the probability set $(0.042<0.05)$.

So the calculated $\mathrm{Z}$ probability value from the rank marked Wilcoxon is smaller than the probability set at $5 \%(\alpha=0.05)$, and from the results of descriptive analysis obtained an average pretest 31.80 and posttest 85.80 , it can be said that the effective lantern application to improve the skills to make lanterns from sewing yarn for deaf children in SLB Negeri 2 Padang.

From the results of statistical test studies that have been analyzed using the SPSS 23 program, Wilcoxon test results obtained a value of 0.042 smaller than $<0.05$, it can be concluded that the hypothesis in this study is the application of effective lanterns to improve the skills to make lanterns from sewing yarn for deaf children in SLB Negeri 2 Padang is acceptable.

\section{CONCLUSION}

Based on the discussion of the results of this study it can be concluded that the application of lanterns is effective in improving the skills to make lanterns from sewing yarn for deaf children of class VIII in SLB N 2 Padang. This is evident from the results of the calculation of data that has been processed using the Wilcoxon Sign Rank test where Z count $=-2,032$ and Asymp sig. (2-tailed) $=0.042$, meaning Z count > Asymp sig. (2-tailed) thus Ho is rejected and Ha is accepted. So the application of effective lanterns to improve the skills of making lanterns from sewing yarn for deaf children class VIII in SLB N 2 Padang.

\section{REFERENCES}

Amirullah, G., \& Susilo. (2016). Aplikasi Education Bahasa Inggris Yang Bisa Diatur Sebagai Alat Pengukur Kemampuan Penguasaan Kosakata Berbasis Android Harison, Busran, Yogi Putra Abstrak Pendahuluan Teknologi komputer saat sangat membantu manusia mengerjakan kegiatan dalam berbagai h, 2, 195200.

Arikunto, S. (2014). Prosedur Penelitian (15th ed.). Jakarta.

Arsyad, A. (2016). Media Pembelajaran (19th ed.). Jakarta.

Ayati, O., \& Iswari, M. (2019). Keterampilan Membuat Herbarium Kering Melalui Model Pembelajaran Explicit Instruction Bagi Anak Tunagrahita Oktrivia Ayati 1 , Mega Iswari 2, 7, 65-70.

Bahagia, Satria, D., \& Ahmadian, H. (2017). Perancangan Sistem Informasi Manajemen Data Korban Bencana Berbasis Mobile Android, 3(2), 22-30. 
Dewi, M. S. (2012). Penggunaan Aplikasi Adobe Photoshop Dalam Meningkatkan Keterampilan Editing Foto, 1, 260-270.

Dona, P., \& Iswari, M. (2018). Model Direct Instruction Untuk Meningkatkan Keterampilan Membuat Layer Cake Variasi Isi Bagi Anak Tunarungu, 6, 165171.

Giyartono, A., \& Kresnha, E. (2015). Aplikasi Android Pengendali Lampu Rumah Berbasis Mikrokontroler Atmega328, (November), 1-9.

Juansyah, A. (2015). Pembangunan Aplikasi Child Tracker Berbasis Assisted Global Positioning System ( A-Gps ) Dengan Platform Android Jurnal Ilmiah Komputer Dan Informatika ( Komputa ). Komputer, Informatika.

Kasijan, Zulmiyetri, \& Iswari, M. (2013). Meningkatkan Keterampilan Mengolah Daging Sapi Menjadi Bakso Melalui Metode Latihan Dengan Pendekatan Keterampilan Proses Bagi Anak Tunarungu Di Smplb Koto Baru Kabupaten Solok, 2(September), 797-807.

Muthia, Y., Aini, Q., \& Iswari, M. (2019). Efektivitas Analisis Tugas Dalam Meningkatkan Keterampilan Membuat Kerupuk Ikan Bagi Anak Tunagrahita Ringan, 7, 160-165.

Oktavini Citra, Irdamurni, Z. (2013). E-Jupekhu E-Jupekhu, 2(September), 117128.

Putri, R. E., \& Iswari, M. (2018). Media Video Tutorial Dalam Keterampilan Membuat Boneka Dari Kaus Kaki Bagi Anak Tunagrahita, 6, 178-185.

Sari, Sri, Yunus, Markis, A. (2015). E-Jupekhu E-Jupekhu, 4(September), 534-541.

Sugiyono. (2016a). Metode Penelitian Kuanttatif, Kualitatif, Dan R\&D (23rd ed.). Bandung.

Sugiyono. (2016b). Metode Penelitian Pendidikan: Pendekatan Kuantitatif, Kualitatif, dan R\&D. Bandung: Alfabeta.

Sulfanita, Seftia, Z. (2018). Pengaruh Model Explicit Instruction dalam Meningkatkan Keterampilan Vokasional Membuat Tempe bagi Anak Tunarungu, 6, 303-307.

Sumekar, G. (2009a). Anak Berkebutuhan Khusus: Cara Membantu Mereka Agar Berhasil dalam Pendidikan Inklusif (1st ed.). Padang.

Sumekar, G. (2009b). Anak Berkebutuhan Khusus: Cara Membantu Mereka Agar Berhasil dalam Pendidikan Khusus (1st ed.). Padang.

Widyawati, C. (2012). Kreasi Lampion Rajut. (Berliyandi, Ed.) (1st ed.). Surabaya. Yetti Annur, Damri, Y. M. (2014). E-JUPEKhu E-JUPEKhu, 3, 11-22.

Zulmiyetri. (2017). Metoda Maternal Reflektif ( MMR ) untuk Meningkatkan Kemampuan Bahasa Lisan Anak Tunarungu, 5, 62-67. 